\title{
Internalisasi Nilai-Nilai Multikultural Melalui Budaya Nyama Beraya Pada Masyarakat Muslim Pegayaman
}

\author{
Ahmad Fauzi \\ Institut Pesantren KH Abdul Chalim Mojokerto \\ Alfauz57@gmail.com
}

\begin{abstract}
;
Nyama Culture is a culture that encourages people to have tolerance attitudes and behaviors for differences because they see others as their own brothers. The form of Nyama culture in Pegayaman is realized by acculturation of local religious and cultural traditions such as the tradition of crossing or the day of cutting off large religious holiday animals such as Eid al-Fitr, Maulid Nabi, Eid al-Adha and several other big celebrations. Where in every celebration of the big day Muslims continue to preserve their ancestral culture, namely Ngejot or provide various types of food to Nyama Hindu. The discussion of this study is 1) The existence of Nyama Beraya culture is influenced by: historical background, cultural acculturation, community cohesiveness, openness of society, Islamic religious ideology. 2) The process of internalizing multicultural values through the culture of Nyama Beraya in Muslim communities pegayaman through three stages, namely: planting, practice and appreciation. 3) The strategy of internalizing multicultural values through the culture of Nyama Beraya in Muslim communities pegayaman consists of: free strategies, traditional strategies and transinternal strategies. 4) The impact of the internalization of multicultural values through the culture of Nyama Beraya in Muslim communities pegayaman includes: no conflict, high spirit of knitting unity and preventing radicalism, growing togetherness, high enthusiasm of the community to maintain the tradition and the friendly welcome of the community.
\end{abstract}

Key word: Internalization, Multicultural Values, Nyama Beraya

\begin{abstract}
Abstrak;
Budaya Nyama merupakan budaya yang mendorong masyarakat agar memiliki sikap dan perilaku toleransi terhadap perbedaan sebab memandang orang lain sebagai saudaranya sendiri. Bentuk budaya Nyama di Pegayaman diwujudkan dengan akulturasi tradisi keagamaan dan budaya setempat seperti tradisi Penampahan atau hari memotong hewan hari raya besar keagamaan seperti Idul Fitri, Maulid Nabi, Idul Adha dan beberapa perayaan besar lain. Dimana dalam setiap perayaan hari besar tersebut umat islam tetap melestarikan budaya leluhur yakni Ngejot atau memberikan berbagai jenis makanan kepada Nyama Hindu. Adapun bahasan penelitian ini ialah 1) Eksistensi budaya Nyama Beraya dipengaruhi oleh: latar belakang sejarah, akulturasi budaya, kekompakan masyarakat, keterbukaan masyarakat, faham keagamaan islam. 2) Proses internalisasi nilai-nilai multikultural melalui budaya Nyama Beraya pada masyarakat muslim pegayaman melalui 3 tahapan yaitu: penanaman, pengamalan dan penghayatan. 3) Strategi internalisasi nilai-nilai multikultural melalui budaya Nyama Beraya pada masyarakat muslim pegayaman terdiri dari: Strategi bebas, Strategi tradisional dan strategi transinternal. 4) Dampak internalisasi nilai-nilai multikultural melalui budaya Nyama Beraya pada masyarakat muslim pegayaman meliputi: tidak ada konflik, tingginya semangat merajut persatuan dan mencegah radikalisme, tumbuhnya kebersamaan, tingginya semangat masyarakat menjaga tradisi dan ramahnya sambutan masyarakat.
\end{abstract}

Kata Kunci: Internalisasi, Nilai-Nilai Multikultural, Nyama Beraya 


\section{Pendahuluan}

Indonesia adalah sebuah bangsa yang plural dan multikultural. Di dalam penelitian etnologis misalnya, diketahui bahwa Indonesia terdiri atas kurang lebih 600 suku bangsa dengan identitasnya masing-masing serta kebudayaannya yang berbeda-beda. Selain dari kehidupan suku-suku tersebut yang terkonsentrasi pada daerah-daerah tertentu, terjadi pula konsentrasi suku-suku di tempat lain karena migrasi atau karena mobilisasi penduduk yang cepat. Melalui sensus 2000 tercatat 101 suku bangsa di Indonesia dengan jumlah total penduduk 201.092.238 jiwa sebagai warga Negara. ${ }^{1}$ Tidak sedikit peneliti yang mengandaikan Indonesia sebagai sebuah melting pot dan sekaligus super market yang ramai bagi pengaruh agama-agama dunia. Agama-agama dunia datang silih berganti. Satu menggantikan yang lain, tetapi dalam arti tertentu juga ada semacam pola amalgamasi, baik antar sesama agama dari luar maupun antara agama luar dengan tradisi agama lokal.

Pluralitas dalam masyarakat mempunyai tanggapan yang berbeda dari pendangan masyarakat secara umum, ada yang mengatakan bahwa aspek pluralisme merupakan sumber konflik sosial ditengah masyarakat, sebagaimana disampaikan Abd. Rahman Assegaf mengutip pernyataan Tobroni dan Samsul Arifin, sebagai berikut:

"Pluraliseme sering dipahami sebagai salah satu faktor pemicu konflik sosial" Abd. Rahman Assegaf menambahkan pendapat dari H.M Sanusi, "Padahal umumnya konflik atau kerusuhan yang terjadi ditengah masyarakat disebabkan faktor dominan ketimpangan sosial," ketimbang agama atau etnis. Assegaf mengutip lagi pendapat Baharuddin, Umat beragama sendiri tidak rusuh dengan sesama mereka, hanya saja umat beragama dijadikan alat untuk mempercepat kerusuhan. ${ }^{2}$

Sering munculnya konflik horizontal di tengah masyarakat pluralis religius, yang mengarah kepada pertentangan SARA, membuat isu tentang peranan agama bagi kelangsungan hidup yang tenteram dan toleran terus menarik untuk diperbincangkan. Sebagai negara yang menempatkan agama sebagai falsafah moral kehidupan berbangsa, adalah penting untuk mengkaji bagaimana peranan pendidikan agama terhadap upaya pemerintah dalam mereduksi konflik yang sering muncul di Tanah Air. Apa yang salah dengan pendidikan agama di Tanah Air sehingga seolah-olah agama sebagai landasan moral bangsa kurang mempunyai peranan signifikan dalam mencegah terjadinya konflik.

Menurut Pengamatan Funinvall, kemajemukan Indonesia ditandai adanya perbedaan-perbedaan suku bangsa, agama, adat dan kedaerahan serta tidak diimbangi dengan pembauran dan memperlihatkan segregasi atau pemisahan masing-masing kelompok sosial. Perkembangan kamajemukan jelas tidak menguntungkan bagi masa depan masyarakat Indonesia karena berpotensi melahirkan konflik sosial secara terbuka. ${ }^{3}$ Kemajukan dalam masyarakat mengisyarakatkan perbedaan, tetapi bila dikelola secara benar kemajemukan menghasilkan kekuatan positif bagi pembangunan bangsa.

Sebaliknya, bila tidak dikelola secara benar, kemajemukan bisa menjadi faktor destruktif atau bersifat merusak menimbulkan bencana yang dahsyat. Konflik dan kekerasan sosial yang sering terjadi antara kelompok masyarakat merupakan bagian dari sikap toleransi yang tidak bisa dikelola dengan baik. ${ }^{4}$ Ketegangan dan konflik di Indonesia seringkali terjadi seperti yang terjadi pada tahun 1990-2000, yakni Situbondo (1996),

\footnotetext{
${ }^{1}$ Suryadinata, Leo, Evi Nurvida Arifin, Penduduk Indonesia, (Jakarta: LP3ES, 2003), 102.

2 Abd. Rahman Assegaf, Politik Pendidikan Nasional, (Yogyakarta: Kurnia Kalam, 2005), 262-263.

3 Nasikun, Sistem Sosial Indonesia, (Jakarta: PT Raja Grafindo Persada,1995), 28.

4 Tobroni, Pendidikan kewarganegaraan Demokrasi, HAM, Civil Society dan Multikultural, (Yogyakarta: PusaPom, 2007), 279.
} 
Tasikmalaya (1997), Kerawang-Bekasi (1997), Ambon (1999), Kupang (1997), dan Mataram (2000). ${ }^{5}$

Hasil dari dua lembaga penelitian yang berbeda menunjukkan bahwa terjadinya pelanggaran kebebasan beragama di indonesia sangat tinggi. Berdasarkan hasil penelitian yang dilakukan oleh The Wahid Institute yang merilis bahwa telah terjadi 158 peristiwa dan 187 tindakan pelanggaran dalam kebebasan beragama dan berkeyakinan yang ada di Indonesia sepanjang tahun $2013 .{ }^{6}$ Hal tersebut juga selaras dengan hasil penelitian yang dilakukan oleh Setara Institute di tahun 2015 yang merilis telah terjadi 196 peristiwa dengan 236 tindangan yang mengarah kepada berbagai pelanggaran kebebasan beragama. Dimana peristiwa dan tindakan tersebut tersebar luas di 26 provinsi yang ada di indonesia. ${ }^{7}$

Adapun faktor-faktor yang memicu terjadinya pelanggaran kebebasan beragama tersebut diantaranya: doktrin agama yang fanatiq dan terlalu subjektif dalam memberikan penilaian terhadap agamanya, dipicu oleh benturan akibat perbedaan suku, ras dan kebudayaan serta timbulnya gesekan antara kaum mayoritas dan minoritas yang tidak terhindarkan. ${ }^{8}$

Hasil penelitian diatas menunjukkan bahwa tren toleransi SARA ( antar suku, agama, ras dan antar gololongan) semakin mengalami defisit dan tentu sangatlah mengkuatirkan bagi bangsa dan negara ini kedepan. Namun kondisi tersebut berbeda dengan apa yang terjadi di kampung muslim pegayaman bali selama berabad-abad. Dimana sampai saat ini konflik yang berorientasi SARA dapat terhindarkan sebab melakatnya kearifan lokal setempat yang oleh masyarakat bali dikenal dengan istilah Budaya Nyama.

Budaya Nyama merupakan budaya yang mendorong masyarakat agar memiliki sikap dan perilaku toleransi terhadap perbedaan sebab memandang orang lain sebagai saudaranya sendiri. Dimana di dalam Budaya Nyama terdapat prinsip bahwa perkataan dan perbuatan baik seseorang terhadap orang lain merupakan bentuk mengasihi dan menyayangi dirinya sendiri. Hal tersebut tentunya menjadi modal sosial yang berkembang dimasyarakat setempat guna menjaga keutuhan dan memudarkan gesekan atas perbedaan. ${ }^{9}$

Kearifan lokal tersebut mendorong terwujudnya harmonisasi di tengah-tengah masyarakat bali. ${ }^{10}$ Sebab mengandung pesan yang bersifat mutlak dan bertahan di lingkungan masyarakat majamuk sebagaimana pesan moral di dalam doktrin agama yang harus dilaksanakan. ${ }^{11}$

Muslim di Kampung Pegayaman menyebut orang Hindu sebagai Nyama Bali begitu pun sebaliknya orang Hindu menyebut Muslim sebagai Nyama Selam. Dimana keduanya memiliki arti saudara. Nyama Bali dan Nyama Selam berkembang di tengah-tengah masyarakat sebagai pengikat layaknya kesepakan yang tidak tertulis dan di junjung tinggi

\footnotetext{
${ }^{5}$ Syamsul Arifin, Studi Agama (Perspektif Sosiologis dan Isu-isu Kontemporer), (Malang: UMM Press, 2009), 70.

${ }^{6}$ Tim Penyusun, Laporan Tabunan Kebebasan Beragama / Berkeyakinan Dan Intoleransi 2014 The Wabid Institute, (Jakarta: The Wahid Institute, 2014), 21.

${ }^{7}$ Halili dan Bonar Tigor Naipospos, Laporan Kondisi Kebebasan Beragama/Berkeyakinan Di Indonesia Tabun 2015, Politik. Harapan Minim Pembuktian (Bendungan Hilir: Pustaka Masyarakat Setara, 2016), 32.

${ }^{8}$ Stev Koresy Rumagit, “ Kekerasan dan Diskriminasi Antar Umat Beragama di Indonesia” dalam Jurnal Lex Administratum, Vol. I, No.2, Januari ( Manado: Universitas SAM Ratulangi, 2013), 59-60.

${ }_{9}^{9}$ Kunawi Basyir, "Membangun Kerukunan Antarumat Beragama berbasis Budaya Lokal Menyama Braya di Denpasar Bali” dalam Jurnal Religio, Vol. 6, No.2, September ( Surabaya: UINSA, 2016), 192.

${ }^{10}$ Nyoman Suryawan, "Kearifan lokal sebagai modal sosial dalam integrasi antara etnik Bali dan etnik Bugis di desa Petang, Badung, Bali” dalam Jurnal Kajian Bali, Vol. 7, No. 1, April ( Tabanan: IKIP Saraswati, 2017), 23-24.

${ }^{11}$ I Made Purna, "Kearifan lokal Masyarakat Desa Mbawa Dalam Mewujudkan Toleransi Beragama" dalam Jurnal Pendidikan dan Kebudayaan, Vol. 1, No. 2, Agustus (Badung: Balai Pelestarian Budaya Bali, NTB dan NTT, 2016), 275,
} 
sampai saat ini. ${ }^{12}$ Sehingga walau terjadi perbedaan SARA, pilihan partai politik dan lain sebagainya tetap dalam kondisi harmonis sebab di ikat oleh sejarah masa lampau dan tardisi yang sudah lama berkembang. ${ }^{13}$

Tokoh masyarakat Pegayaman, Komang Sohibul Islam yang juga menjabat sebagai Ketua Badan Permusyawaratan Desa (BPD) mengatakan toleransi beragama di desa pegayaman sudah berjalan sejak ratusan tahun lalu. Warga Muslim telah bermukim di desa itu sejak pertama kali berdiri Kerajaan Buleleng di bawah kepemimpinan Ki Barak Panji Sakti sekitar awal abad ke-16. Beliau mengatakan: ${ }^{14}$

"Kami telah diajarkan oleh para orang tua kami mengenai apa yang kami lakukan dan kami yakini saat ini. Di desa kami punya pandangan bahwa semua adalah saudara. Sejak dahulu kala bukan baru-baru ini saja saat kata toleransi mulai digaung-gaungkan. Semua umat di dunia ini memang adalah bersaudara. Tidak ada yang membeda-bedakan. agama adalah keyakinan setiap orang yang harus dihargai dan tidak boleh disamakan. dewasa ini dimana masalah radikalisme menjadi bahasan hangat kami mengajak semuanya untuk bangkit dari perbedaan karena memang kita semua adalah bersaudara. Maka masyarakat di desa pengayaman menyebut semua dengan sebutan Nyama. Adapun Nyama bermakna Jika kita memang bersaudara mengapa kita harus bermusuhan dan saling membenci? Bukankah bersaudara harus saling mengasihi dan menyayangi."

Bentuk budaya Nyama di Pegayaman diwujudkan dengan akulturasi tradisi keagamaan dan budaya setempat seperti tradisi Penampahan atau hari memotong hewan hari raya besar keagamaan seperti Idul Fitri, Maulid Nabi, Idul Adha dan beberapa perayaan besar lain. Dimana dalam setiap perayaan hari besar tersebut umat islam tetap melestarikan budaya leluhur yakni Ngejot atau memberikan berbagai jenis makanan kepada Nyama Hindu.

Hal yang sama akan dilakukan oleh umat Hindu di daerah itu. Tentu pemberian dari umat Hindu disepakati merupakan berbagai makanan yang tidak mengandung daging babi. Selain itu ada tradisi membuat orang-orangan semacam ogoh-ogoh di Bali setiap perayaan Idul Fitri, penggunaan nama khas bali di depan nama seseorang (Wayan, Kadek, Made, Komang dan Ketut), tradisi Sokok Sada Maulid Basa dan Jero Lingga berbasis musyawarah antaragama. ${ }^{15}$ Tradisi-tradisi tersebut merupakan bagian dari budaya Nyama dalam merekatkan kebersamaan dalam masyarakat muslim desa pegayaman menuju islam yang moderat, mengakui suatu perbedaan dan merajut persatuan bangsa guna menangkal radikalisme yang berkembang saat ini di indonesia ini.

\section{Eksistensi Budaya Nyama Beraya di Lingkungan Masyarakat Bali}

Keberadaan Budaya Nyama Beraya sudah lama berkembang dan melekat pada diri masyarakat Bali sejak zaman dahulu kala tepatnya semenjak terjadinya perkawinan silang antara kasatria utusan kerajaan mataram yang menganut agama Islam dengan wanita abdi dalem puri di era Ki Barak Panji Sakti yang beragama Hindu sehingga menyebabkan akulturasi relasi islam dan hindu yang berbuah toleransi antar agama.

\footnotetext{
12 I Gede Suwindia , Machasin, I Gede Parimartha, "Relasi Islam dan Hindu Perspektif Masyarakat Bali" dalam Jurnal Al-Ulum, Vol. 12, No. 1, Juni (Gorontalo: LP2M IAIN Sultan Amai, 2012), 53-76.

${ }^{13}$ I Made Pageh, Wayan Sugiartha,Ketut Sedana Artha, “ Analisis Faktor Integratif Nyama Bali-Nyama Selam, Untuk Menyusun Buku Panduan Kerukunan Masyarakat di Era Otonomi daerah” dalam Jurnal Ilmu Sosial dan Humaniora, Vol. 2, No. 2, Oktober ( Singaraja: Universitas Pendidikan Ganesha, 2013), 240.

${ }^{14}$ Hasil wawancara dengan kepala Tokoh masyarakat Pegayaman yaitu bapak Komang Sohihul Islam yang juga menjabat sebagai Ketua Badan Permusyawaratan Desa. (Buleleng, 13 Maret 2018)

${ }^{15}$ Hasil Survei Peneliti di Kampung Muslim Pegayaman. (Buleleng, 13 Maret 2018)
} 
Hal tersebut terus berlanjut dan berkembang sampai era modern saat ini sehingga masyarakat bali berhasil membangun harmoni sosial di tengah kompleksitas keragaman (etnis, budaya, dan agama) dengan memanfaatkan local wisdom dalam membangun kesadaran keragaman dan perbedaan (pluralisme) yang berbasis pada budaya menyama braya. ${ }^{16}$ Keharmonian tersebut berdampak kepada gagalnya setiap orang atau kelompok yang mencoba memanfaatkan etnositas dan isu SARA pada lingkungan masyarakat sekitar pada saat hajatan politik baik pilkada, pilgub maupun pilpres karena faktor ikatan sejarah dan merekatnya tradisi penyamabrayaan dalam diri masyarakat Bali. ${ }^{17}$

Kerukunan umat beragama di Bali sudah terjalin dengan baik dengan sistem budaya yang disebut nyama braya yang artinya saudara, kerabat, saudara dekat sehingga temanteman yang non-Hindu ataupun non-Bali sudah dianggap sebagai kerabat. Salah satu yang bisa diambil contoh wujud kerukunan yang terjadi antara masyarakat Islam dan masyarakat Hindu adalah hubungan sosial seperti perkawinan diantara keduanya, saling menjaga keamanan pada saat masyarakat Islam mengadakan acara begitu juga sebaliknya. ${ }^{18}$

Interaksi Nyama Bali dan Nyama Selam yang telah berlangsung beberapa abadabad lamanya mendorong mereka untuk saling mempengaruhi baik dari segi sosial maupun budaya. Hal ini dibuktikan dengan berbagai peminjaman identitas etnik di kampung muslim di desa Pegayaman, dusun Saren Jawa desa Budakeling menggunakan nama depan khas Bali seperti Wayan, Putu, Made, Nengah, Komang, Nyoman, Ketut. Pengunaan bahasa Bali, saling kunjungi dalam acara adat, ritual, dan acara penting dalam kehidupan sehari-hari dapatmemperkuat integrasi, di kalangan umat muslim di daerah-daerah seperti Saren Jawa, Desa Gelgel, Kepaon (Denpasar) dengan ciri menu masakan ala Bali seperti lawar dengan tidak memakai darah dan daging babi, sate lilit, komoh, tum, urab dan pembuatan Bebangkit Selam di Angantiga. ${ }^{19}$

Selain itu interaksi tersebut merupakan modal sosial masyarakat dalam mendorong terciptanya integrasi sosial seperti adanya tradisi ngejot pada waktu umat Hindu mengadakan upacara keagamaan seperti hari raya Galungan dan Nyepi, pada waktu yang baik tersebut umat muslim memberikan buah atau jajanan, begitu juga sebaliknya pada waktu Idul Fitri masyarakat Hindu ngejot buah ke saudara islamnya. ${ }^{20}$

Hal ini sesuai dengan hasil penelitian yang peneliti peroleh di lingkungan masyarakat pegayaman kecamatan sukasada kabupaten buleleng yang mayoritas beragama islam . Dimana eksistensi budaya Nyama Beraya sangat kuat dan membudaya pada diri masyarakat pegayaman sehingga menjadi kebiasaan dan tradisi dalam kehidupan sehari-hari. Adapun yang menjadi faktor kuatnya pengaruh budaya Nyama Braya di kampung muslim pegayaman diantanya yaitu :

a. Latar belakang sejarah terbentuknya desa pegayaman sejak masa Ki Barak Panji Sakti abad ke-16 telah membentuk kepribadian masyarakat pegayaman sampai

\footnotetext{
${ }^{16}$ Kunawi Basyir, "Membangun Kerukunan Antarumat Beragama berbasis Budaya Lokal Menyama Braya di Denpasar Bali" dalam Jurnal Religio, 188

${ }^{17}$ I Made Pageh, Wayan Sugiartha,Ketut Sedana Artha, "Metode Analisis Faktor Integratif Nyama Bali-Nyama Selam , untuk Menyusun Buku Panduan Kerukunan masyarakat di Era Otonomi Daerah “ dalam Jurnal lmu Sosial dan Humaniora, 420.

18 Wildaniati, I Putu Gede Suwitha, Fransiska Dewi Setiowati Sunaryo, "Dinamika Kerukunan Antar Umat Beragama Eksistensi Masyarakat Islam di Bali Pasca Bom Bali Tahun 2002-2012” dalam Jurnal Humanis, 127132.

19 I Made Pageh, Wayan Sugiartha,Ketut Sedana Artha, "Metode Analisis Faktor Integratif Nyama BaliNyama Selam , untuk Menyusun Buku Panduan Kerukunan masyarakat di Era Otonomi Daerah “ dalam Jurnal lmu Sosial dan Humaniora, 422.

${ }^{20}$ I Made Pageh, Wayan Sugiartha,Ketut Sedana Artha, "Metode Analisis Faktor Integratif Nyama BaliNyama Selam , untuk Menyusun Buku Panduan Kerukunan masyarakat di Era Otonomi Daerah “ dalam Jurnal lmu Sosial dan Humaniora, 422.
} 
saat ini sehingga menyebabkan kuatnya eksistensi budaya Nyama Braya dalam kehidupan mereka sehari-hari. Hal ini terjadi sebagai konsekuensi dari keteguhan dan kegigihan nenek moyang mereka dalam memepertahankan dan merawat kearifan lokal tersebut dari masa ke masa serta mampu menurunkannya kepada generasi penerus sampai saat ini.

b. Akulturasi budaya hindu dan islam yang ikut mewarnai bahasa dan kesenian dalam kehidupan masyarakat pegayaman. hal ini dapat dibuktikan dengan bahasa yang mereka gunakan dalam percakapan dan bersikap yang masih lekat dengan bahasa bali sehingga secara otomatis dari bahasa nenek moyang mereka dahulu yang beragama hindu memepengaruhi cara mereka dalam berfikir dan bertindak dalam kehidupan sehari hari. Selain itu akulturasi ini juga ikut mempengaruhi perkembangan kesenian masyarakat pegayaman sebab kesenian yang ditampilkan tidak bisa dilepaskan dari budaya hindu yang melekat dan kental sekali. Adapun contohnya penampilan seni burdah pegayaman yang alat musik, pakaian penari dan kidung yang digunakan tidak bisa dilepaskan dari budaya hindu bali namun walau demikian akulturasi ini tidak melanggar syariat islam.

c. Kekompakan masyarakat pegayaman dalam melestarikan tradisi-tradisi yang diajarkan nenek moyangnya seperti ngejot, sukok sada maulid basa, jero linggo, penamaan khas bali pada nama depan mereka dan ejaan iqro' yang menggunakan bahasa bali.

d. Keterbukaan masyarakat pegayaman terhadap informan, peneliti dan masyarakat luar untuk mengekplorasi budaya Nyama Braya dan memperkenalkannya kepada khalayak umum. Dengan keterbukaan ini sangat besar sekali untuk bertahan dan dapat berkembang di tengah-tengah masyarakat indonesia sebab dapat menjadi informasi bagi masyarakat muslim pada khususnya dan dunia pada umumnya guna sebagai kampung percontohan dalam bidang multikultural dan penangkal radikalisme yang berkembang pesat saat ini .

e. Faham keagamaan islam yang dianut sebagian besar di kampung muslim pegayaman ialah ahlusunnah waljamaah yang memiliki 4 prinsip yaitu tawazzun ( berimbang), tasamuh (toleransi), taad'ul ( adil) dan tawassut (moderat)." Sehingga sangat menerima budaya Nyama Braya sebagai warisan leluhur untuk di kembangkan di tengah-tengah masyarakat.

\section{Proses Internalisasi Nilai-Nilai Multikultural Melalui Budaya Nyama Beraya Pada Masyarakat Bali}

Proses terjadinya internalisasi nilai-nilai multikultural tidak dapat dilepaskan dari 3 tahapan yang harus dilalui oleh seorang individu diantaranya dapat dijelaskan sebagai berikut : ${ }^{21}$

a. Tahap Transformasi Nilai

Tahap ini merupakan suatu proses yang dilakukan oleh seseorang dalam menginformasikan nilai-nilai yang baik dan kurang baik. Pada tahap ini hanya terjadi komunikasi verbal antara individu dengan individu lain.

b. Tahap Transaksi Nilai

Suatu tahap pendidikan nilai dengan jalan melakukan komunikasi dua arah, atau interaksi antar individu yang bersifat interaksi timbal-balik.

c. Tahap Transinternalisasi

\footnotetext{
${ }^{21}$ Muhaimin, Srategi Belajar Mengajar, (Surabaya: Citra Media, 1996), 153.
} 
Tahap ini jauh lebih mendalam dari tahap transaksi. Pada tahap ini bukan hanya dilakukan dengan komunikasi verbal tapi juga sikap mental dan kepribadian. Jadi pada tahap ini komunikasi kepribadian yang berperan secara aktif.

Selain itu transinternalisasi nilai dapat dilihat dari beberapa indikator berikut: ${ }^{22}$

1) Receiving (menyimak), yakni kegiatan peserta didik untuk bersedia menerima adanya stimulus yang berupa nilai baru yang dikembangkan dalam sikap afektifnya.

2) Responding (menanggapi), yakni kesediaan peserta didik untuk merespon nilai yang ia terima dan sampai ke tahap memiliki kepuasan untuk merespon nilai tersebut.

3) Valuing (memberi nilai), yakni sebagai kelanjutan dari aktifitas nilai menjadi peserta didik mampu memberikan makna baru terhadap nilai yang muncul dengan kriteria nilai yang diyakini kebenarannya.

4) Organization of value (mengorganisasi nilai), yakni aktifitas peserta didik untuk mengatur berlakunya sistem nilai yang ia yakini sebagai kebenaran dalam laku kepribadiannya sendiri sehingga ia memiliki satu sistem nilai yang berbeda dengan orang lain.

5) Characterization by a value or value complex (karakteristik nilai), yakni dengan membiasakan nilai yang benar yang diyakini, dan yang telah diorganisir dalam laku pribadinya. Sehingga nilai tersebut sudah menjadi kepribadiannya yang tidak dapat dipisahkan lagi dari kehidupannya.

Adapun Tujuan pembelajaran secara garis besar memuat tiga aspek pokok, yaitu knowing, doing, dan being atau dalam istilah umum dikenal dengan aspek kognitif, psikomotor, dan afektif. Internalisasi merupakan pencapaian aspek yang terakhir yaitu being. ${ }^{23}$ Penjelasan mengenai ketiga aspek tujuan pembelajaran tersebut adalah sebagai berikut:

a. Mengetahui (knowing)

Tugas guru pada aspek ini adalah mengupayakan agar siswa mengetahui suatu konsep. Dalam bidang keagamaan misalnya siswa diajar mengenai pengertian sholat, syarat sah sholat, syarat wajib sholat, rukun sholat, dan tata cara sholat. Guru bisa menggunakan berbagai metode, seperti: diskusi, tanya jawab, dan penugasan. Untuk mengetahui pemahaman siswa mengenai apa yang telah diajarkan, guru melakukan ujian atau memberikan tugas-tugas rumah. Jika nilainya bagus berarti aspek ini telah selesai dan sukses.

b. Mampu Melaksanakan (doing)

Guru dapat menggunakan metode demonstrasi untuk mencapai tujuan pada aspek ini. Sebagai contoh pada materi sholat, seorang guru dapat mendemonstrasikan sholat untuk diperlihatkan kepada siswa atau bisa juga dengan memutarkan film tentang tata cara sholat, selanjutnya siswa secara bergantian mempraktikkan seperti apa yang telah dilihat di bawah bimbingan guru. Untuk tingkat keberhasilannya guru dapat mengadakan ujian praktik sholat, dari ujian tersebut dapat dilihat apakah siswa telah mampu melakukan sholat dengan benar atau belum.

c. Menjadi Kepribadian (being)

22 Muhaimin, Paradigma Pendidikan Islam: Upaya Mengaktifkan Pendidikan Agama Islam di Sekolah, (Bandung: PT Remaja Rosdakarya, 2004), 178.

23 Ahmad Tafsir, Filsafat Pendidikan Islam, Integrasi Jasmani, Rohani, dan Kalbu Memanusiakan Manusia (Bandung: Remaja Rosdakarya, 2006), 229. 
Konsep ini seharusnya tidak sekedar pada nilai karakter menjadi milik siswa, tetapi nilai karakter tersebut menjadi satu dengan kepribadian siswa. Siswa melaksanakan sholat yang telah dipelajari dalam kehidupan sehari-hari. Ketika sholat telah melekat menjadi kepribadian siswa, seorang siswa akan bersungguh-sungguh untuk menjaga sholatnya dan akan merasa sangat berdosa jika sampai meninggalkan sholat. Jadi siswa melaksanakan sholat bukan karena diperintah atau dinilai oleh guru.

Proses pendidikan yang paling sulit ada pada aspek ini, karena pada aspek being tidak dapat diukur dengan cara yang diterapkan pada aspek knowing dan doing. Aspek ini lebih menekankan pada kesadaran siswa untuk mengamalkannya. Selain melalui proses pendidikan di sekolah perlu adanya kerja sama dengan pihak orang tua siswa, mengingat waktu siswa lebih banyak digunakan di luar sekolah. Kesadaran seseorang dalam melakukan suatu tindakan tertentu akan muncul tatkala tindakan tersebut telah dihayati (terinternalisasi).

Sedangkan dalam ilmu tasawuf proses terjadinya internalisasi dikenal dengan istilah takhalli, tahalli dan tajalli yang dapat diuraikan sebagai berikut:

a. Takhalli

HM. Amin Syukur, sebagai contoh, menegaskan bahwa takhalli berarti membersihkan diri dari sifat-sifat tercela, kotoran dan penyakit hati yang merusak. Sedangkan Mustafa Zahri merumuskan takhalli sebagai upaya mengosongkan diri dari segala sifat-sifat yang tercela. ${ }^{24} \mathrm{M}$. Hamdani Bakran al-Dzaky menjelaskan bahwa takhalli yaitu metode pengosongan diri dari bekasan kedurhakaan dan pengingkaran dosa terhadap Allah Swt dengan jalan melakukan tobat yang sesungguhnya (taubatan nasubah). ${ }^{25}$

Ramayulis menjelaskan bahwa takhalli scara umum diartikan sebagai membersihkan diri dari sifat-sifat tercela, dari maksiat lahir dan maksiat batin, mengosongkan diri dari sifat-sifat ketergantungan terhadap kenikmatan dunia. Cara pencapaian takhalli adalah dengan cara menjauhkan diri dari kemaksiatan dalam segala bentuk dan berusaha melenyapkan dorongan hawa nafsu jahat. ${ }^{26}$

\section{b. Tahalli}

Menurut HM. Amin Syukur, tahalli adalah menghias diri dengan cara membiasakan sifat, sikap dan perbuatan yang baik. Sedangkan Mustafa Zahri mengartikan tahalli yaitu menghias diri dengan sifat-sifat terpuji. ${ }^{27}$ Untuk melakukan tahalli, langkahnya adalah membina pribadi, agar memiliki akblâqul karimah dan selalu konsisten dengan langkah yang dirintis sebelumnya dalam takhalli. Melakukan latihan kejiwaan yang tangguh untuk membiasakan berprilaku baik, yang pada gilirannya akan menghasilkan manusia yang sempurna (insân kâmil).

\section{c. Tajalli}

Menurut Mustafa Zahri, tajalli adalah lenyapnya atau hilangnya bijâb dari sifatsifat manusiawi, jelasnya cahaya yang selama itu ghaib, lenyapnya segala yang lain ketika nampaknya wajah Allah Swt. ${ }^{28}$ Sedangkan Hasyim Muhammad menyatakan

\footnotetext{
${ }^{24}$ Mustafa Zahri, Kunci Memahmi Ilmu Tasawuf, (Surabaya: Bina Ilmu, 1995), 26 dan 74.

${ }^{25}$ M. Hamdani Bakran al-Dzaky, Konseling dan Psikoterapi Islam Penerapan Metode Sufistik, (Yogyakarta, Fajar Pustaka Baru, 2002), 259.

${ }^{26}$ Ramayulis, Pengantar Psikologi Agama, (Jakarta: Kalam Mulia, 2002), 138.

${ }^{27}$ Mustafa Zahri, Kunci Memahami Ilmu Tasawuf, 82-89.

${ }^{28}$ Mustafa Zahri, Kunci Memahami Ilmu Tasawuf, 245.
} 
bahwa tajalli adalah lenyapnya sifat-sifat kemanusiaan yang digantikan dengan sifat-sifat ketuhanan. Menurut M. Hamdani Bakran al-Dzaky, tajalli adalah kelahiran atau munculnya eksistensi yang baru dari manusia, yaitu perbuatan, ucapan, sikap dan gerak-gerik yang baru, martabat dan status yang baru, sifat-sifat dan karakteristik yang baru, dan esensi diri yang baru. Itulah yang disebut dengan kemenangan dari Allah Swt.

Telah lahirnya seseorang dari kelahiran yang baru dan di dalam hidup dan kehidupan yang baru adalah semata-mata karena pertolongan Allah Swt, syafâ'at Nabi Muhammad Saw dan doa para malaikat di sisi-Nya melalui upaya, perjuangan, pengorbanan dan kedisiplinan yang sangat tinggi dari diri sendiri dalam melaksanakan ibadah-ibadah berupa melaksanakan segala perintah-Nya, menjauhi larangan-Nya dan tabah terhadap ujian-Nya.

Hal tersebut relevan dengan data yang peneliti peroleh dilapangan bahwa proses internalisasi nilai-nilai multikultural melalui budaya Nyama Beraya pada masyarakat muslim pegayaman terjadi melalui 3 proses tahapan yaitu penanaman nilai, pengamalan nilai dan penghayatan nilai yang dapat dijelaskan sebagai berikut:

a. Penanaman Nilai

Penanaman nilai dilakukan dengan menanamkan nilai kepada masyarakat pegayaman yang dilakukan dengan beberapa metode diantaranya perintah , nasehat, tauladan, teguran , pembiasaan dan diskusi. Adapun yang ditanamkan merupakan nilai-nilai yang terkandung dalam budaya Nyama Beraya yaitu toleransi atas dasar persaudaraan dan saling mengasihi sebagai manusia yang berbudaya . Penanaman nilai-nilai ini dilakukan secara terus menerus kepada generasi muda dengan harapan mereka dapat memegang prinsip-prinsip ajaran nenek moyang mereka yaitu Menyama Beraya dan menjadikannya pedoman dalam bersikap serta berperilaku dalam kehidupan sehari hari.

b. Pengamalan Nilai

Pengamalan nilai merupakan kelanjutan dari penanaman nilai dimana pada tahap ini terjadi pembiasaan yang mengarah kepada terbentunya budaya Nyama Beraya di desa pegayaman. Kebiasaan tersebut dilakukan secara terus menerus baik itu secara langsung maupun spontan dan menjadi bagian hidup masyarakat dalam melaksanakan rutinitasnya sehari-hari. Selain itu kebiasaan tersebut akan berkembang menjadi budaya masyarakat setempat yang dipegang teguh untuk dilaksanakannya sehingga tidak mudah bagi orang luar untuk menanamkan nilainilai baru dan bertentangan dengan kebiasaan yang sudah mendarah daging serta mengakar pada masyarakat muslim pegayaman.

c. Penghayatan Nilai

Penghayatan nilai merupakan peresapan terhadap nilai-nilai yang sudah ditanamkan dan diamalkan dalam kehidupan sehari-hari. Nilai yang sudah terserap dan masuk di dalam jiwa setiap individu masyarakat pegayaman ini akan mendorong ia untuk meyakini kebenaran nilai tersebut dan membentuk mental serta kepribadiannya dalam berperilaku. Selain itu pada tahap ini setiap individu akan semakin yakin dan mantap terhadap kebenaran yang ia poroleh selama ini serta sangat sulit sekali untuk merubah mainset yang di milikinya.

Ketiga tahapan tersebut secara tidak langsung merasuk pada diri masyarakat pegayaman baik anak-anak, remaja, pemuda maupun orang tua sebab sudah berkembang dengan sangat pesat dan membudaya serta menjadi kebiasan yang sulit sekali dicegah, turun temurun ditularkan dari generasi ke generasi selanjutnya sampai saat ini melalui perintah dan nasehat-nasehat yang diberikan oleh orang tua mereka. 
Selain itu faktor tradisi dan budaya pegayaman yang juga memiliki andil besar dalam mempengaruhi kehidupan masyarakat baik di dilingkungan keluarga, sekolah, komunitas kesenian daerah dan masyarakat desa.

\section{Strategi Internalisasi Nilai-Nilai Multikultural Melalui Budaya Nyama Beraya Pada Masyarakat Bali}

Kearifan lokal yang terbangun melalui budaya Nyama Beraya guna menumbuhkan sikap dan perilaku multikultural dalam kehidupan sehari-hari tidak bisa dilepaskan dari beberapa strategi yang digunakan untuk menginternalisasi nilai pada diri individu sebagaimana A. Fatah Yasin yang mengutip uraian muhaimin sebagai berikut dari:

a. Strategi tradisional, yaitu memberitahukan secara langsung kepada seseorang tentang nilai-nilai yang dianggap baik dan yang kurang baik.

b. Strategi bebas, yaitu individu tidak memberitahukan secara langsung kepada individu lain tentang nilai-nilai yang dianggap baik atau buruk namun memberikan kesempatan untuk memilih secara bebas karena nilai yang dianggap baik oleh seseorang belum tentu baik pula menurut orang lain.

c. Strategi reflektif yaitu bolak balik menggunakan pendekatan teoritik ke emperik atau deduktif ke induktif.

d. Strategi transinternal yaitu cara untuk mendidik nilai dengan melakukan transformasi nilai, dilanjutkan dengan transaksi lain dan transinternalisasi. ${ }^{29}$

Hal tersebut sesuai dengan data lapangan yang peneliti dapatkan dimana dalam menginternalisasikan nilai-nilai multikultural melalui budaya Nyama Beraya pada masyarakat muslim pegayaman terdiri dari beberapa strategi diantaranya:

a. Stretegi Tradisional

Strategi ini ditempuh dengan memberikan informasi secara langsung terkait dengan nilai-nilai yang terkandung di dalam budaya Nyama Beraya kepada seseorang di dalam lingkungan masyarakat pegayaman melalui nasehat, teguran, perintah dan indoktrinasi. Strategi dilakukan dalam rangka untuk menanamkan nilai-nilai kepada diri seseorang dengan tujuan terbentuknya karakter yang menggiring individu tersebut untuk mengikuti apa yang diharapkan. Selain itu strategi ini secara langsung mencoba untuk mondorong seseorang melakukan segala aktivitas dan runtinitas kebudayaan yang sudah berkembang di pegayaman selama beratus-ratus tahun sampai saat ini.

b. Strategi Bebas

Strategi ini memberikan peluang dan kesempatan kepada seseorang di tengahtengah masyarakat pegayaman untuk bebas berekspresi tanpa tekanan dan intruksi dari siapapun namun justru sebaliknya individu tersebut menemukan sendiri secara langsung maupun tidak langsung nilai-nilai yang terkandung di dalam budaya Nyama Beraya. Selain itu strategi ini menggiring seseorang untuk menentukan sendiri nilai-nilai yang dirasa baik dan memiliki nilai manfaat bagi siapapun. Masyarakat merupakan media yang mendorongnya untuk menemukan dan menentukan arah baginya dalam menjalankan ajaran lelulur yaitu Menyama Beraya.

c. Strategi Transinternal

Strategi ini ditempuh dengan mentransfer nilai-nilai yang terkandung dalam budaya Nyama Beraya melalui penanaman nilai kepada seseorang dengan tujuan orang tersebut melaksanakannya dalam kehidupan sehari hari dan menjadikannya

${ }^{29}$ A. Fatah Yasin, Dimensi-Dimensi Pendidikan Islam, (Malang: UIN MALANG PRESS, 2008), 158-159. 
sebagai rutinitas yang tidak terlepas dari nilai-nilai budaya. Jika hal ini terjadi secara terus menerus akan menyebabkan masuknya nilai-nilai tersebut kedalam diri individu dan individu tersebut dapat menghayatinya sehingga dalam melakukan segala aktivitas tidak ada beban dan keragu-raguan namun penuh dengan percaya diri.

Berbagai strategi diatas yang dilakukan oleh masyarakat pegayaman guna menjaga kearifan lokal dan kokohnya tradisi Nyama Beraya di lingkungan desa yang bertujuan untuk menangkal pengaruh dan dominasi kelompok ekstrimis maupun kelompok radikal lainnya yang akhir-akhir ini mulai muncul dengan menggunakan berbagai macam cara baik secara langsung berdakwa di kampung pegayaman, melalui media online dan media massa ataupun cara halus berupa pemberian bantuan yang memiliki tujuan-tujuan tertentu dalam rangka merusak ajaran leluhur tersebut . Namun sampai saat ini pengaruh dari luar tersebut kurang berhasil dan tidak mendapat dukungan dari masyarakat sekitar.

\section{Dampak Internalisasi Nilai-Nilai Multikultural Melalui Budaya Nyama Beraya Pada Masyarakat Bali}

Dampak internalisasi nilai-nilai multikultural akan membuahkan hasil berupa karakter yang dituangkan dalam bentuk sikap dan perilaku seorang individu dalam kehidupan sehari-hari sehingga tercipta hubungan yang harmonis tanpa melihat suatu perbedaan namun mengedepankan kerukuran dan persatuan.

Karakter merupakan deskripsi dari perilaku manusia yang berorientasi pada nilainilai logika dan etika baik secara eksplisit dan implisit. ${ }^{30}$ Karakter maupun kepribadian merupakan perilaku manusia yang relatif permanen, membimbing dan mendorong untuk beraktivitas dalam kehidupan serta berorientasi pada lingkungan sosial masyarakat. ${ }^{31}$

Karakter ialah keinginan manusia yang berorientasi pada tujuan-tujuan yang ingin dicapai. Dimana pada esensinya terkandung nilai etika dan moral. ${ }^{32}$ Jadi karakter ialah keinginan dan kebiasaan manusia yang berorientasi pada tujuan-tujuan yang positif. Sehingga manusia yang berkarakter ialah manusia yang memiliki hasrat dan prilaku positif yang dituangkan dalam kebiasaan sehari-hari. Maka dapat disimpulkan bahwa karakter merupakan deskripsi prilaku manusia yang mengarah pada nilai dan norma yang berkembang di masyarakat.

Adapun karakter yang dihasilkan dari internalisasi nilai-nilai multikultural dalam diri seseorang individu yaitu karakter toleransi. Menurut UNESCO, toleransi adalah sikap saling menghormati, saling menerima dan saling menghargai ditengah keragaman budaya, kebebasan berpendapat dan karakter manusia. Toleransi tersebut harus didukung oleh pengetahuan yang luas, sikap terbuka, dialog, kebebasan berpikir dan beragama. UNESCO menambahkan bahwa toleransi juga berarti sebuah sikap positif dengan cara menghargai hak orang lain dalam rangka menggunakan kebebasan asasinya sebagai manusia. ${ }^{33}$ Sedangkan menurut Asyraf Abdul Wahhab, Toleransi dalam konteks sosial-budaya merupakan sebuah keniscayaan. Pada hakikatnya, setiap masyarakat yang plural membutuhkan kedamaian dan perdamaian. Kedua hal tersebut adalah toleransi. ${ }^{34}$

\footnotetext{
30 Alwisol, Psikologi Kepribadian,(Malang: UNMU, 2007), 8.

31 Arismantoro.Character Building: $\quad$ Bagaimana Mendidik Anak Berkarakter, (Yogyakarta: Tiara Wacana, 2008), 27.

32 W.S. Winkel \& Sri Hastuti, bimbingan dan konseling di institusi pendidikan, (Jogjakarta: media abadi, 2004), 218.

33 Moh. Yamin, Vivi Aulia, Meretas Pendidikan Toleransi : Pluralisme dan Multikulturalisme keniscayaan Peradaban, (Malang: Madani Media, 2011), 6.

${ }_{34}$ Moh. Yamin, Vivi Aulia, Meretas Pendidikan Toleransi : Pluralisme dan Multikulturalisme keniscayaan Peradaban, 7.
} 
Dalam konteks demikian, hakikat toleransi adalah hidup berdampingan dengan damai dan saling menghargai keragaman yang dibuktikan melalui tindakan, sikap, dan perilaku antara individu maupun kelompok denganindividu maupun kelompok lainnya. Toleransi merupakan keniscayaan yang tidak dapat dihindari atau ditolak akan tetapi menjadi bagian hidup manusia dan bukan untuk diingkari sehingga menyebabkan konflik baik antar individu maupun kelompok.

Toleransi adalah kemampuan untuk menghormati sifat dasar, keyakinan dan perilaku yang dimiliki oleh orang lain. Dalam literatur agama islam, toleransi disebut dengan tasamuh yang dipahami sebagai sifat atau sikap menghargai, membiarkan, atau membolehkan pendirian (pandangan) orang lain yang tidak bertentangan dengan pandangan kita. Secara prinsip metodologis, toleransi adalah penerimaan terhadap yang tampak sampai kepalsuannya tersingkap. Toleransi relevan dengan epistemologi. Ia juga relevan dengan etika, yaitu sebagai prinsip menerima apa yang dikehendaki sampai ketidaklayakan tersingkap. Dan toleransi adalah keyakinan bahwa keanekaragaman agama terjadi karena sejarah dengan semua faktor yang memengaruhinya, baik kondisi ruang, waktu, prasangka, keinginan, dan kepentinannya yang berbeda antara satu agama dengan agama lainnya. ${ }^{35}$

Hal tersebut sesuai dengan data yang peneliti dapatkan secara trianggulasi baik melalui wawancara, observasi dan dokumentasi berupa dampak dari internalisasi nilai-nilai multikultural melalui budaya Nyama Beraya pada masyarakat muslim pegayaman yang dapat dijelaskan sebagai berikut :

a. Tingginya semangat masyarakat pegayaman dalam menjaga dan melestarikan toleransi ditengah-tengah keberagaman. Tingginya toleransi ini tidak bisa dilepakaskan oleh ajaran lelulur untuk senantiasa menghargai semua perbedaan yang ada selama beratus-ratus tahun lamanya. Toleransi ini tetap terjalin erat sampai saat ini sebab sudah membentuk karakter masyarakat pegayaman.

b. Minimnya perkelahian antar remaja di pegayaman. Hal ini dibuktikan dengan data dilapangan yang sampaikan oleh aparatur desa, masyarakat dan warga sekolah selama satu tahun belakangan ini.

c. Persaudaran yang kuat antar orang pegayaman dan juga pendatang serta tetangga desa yang berbatasan langsung dengan pegayaman terbagun sampai saat ini . Hal tersebut disebabkan oleh rasa memiliki satu sama lain yang tertanam dalam diri masyarakat pegayaman sehingga jika terjadi hal yang mengarah kepada konflik timbul rasa empati yang luar biasa untuk mengatasinya.

d. Tidak ada konflik yang mengatasnamakan agama mapun golongan di pegayaman . Konflik yang pernah ada namun hampir tidak ada dalam 1 tahun di pegayaman merupakan konflik pribadi individu dan individu lain. Hal ini sebagai akibat dari bertahannya wawarisan lelehur yang ada di pegayaman sampai saat ini sehingga walaupun sekarang masuk masa pemilukada dan pilpres secara nasional yang mambawa isu agama maupun golongan tidak akan membawa dampak yang signifikan di pegayaman. Sebab jauh sebelum berdirinya NKRI dan pemilu tahun 1955 yang cenderung memiliki karakteristik golongan masyarakat pegayaman tidak terpengaruh dan memilih sesusai dengan hati nurani.

e. Tingginya semangat masyarakat pegayaman untuk merajut persatuan dan mencegah munculnya radikalisme di lingkungan sekitar dilakukan oleh semua warga melalui penanaman langsung kepada generasi penerus melalui berbagai kegiatan yang ada di pegayaman baik waktu melakukan tradisi, pergelaran

35 Ngainun Naim dan Achmad Sauqi, Pendidikan Multikultural Konsep dan Aplikasi, (ArRuzz Media: Yogyakarta, 2011), 77. 
kesenian, kegiatan desa maupun melalui kegiatan yang menjadi rutinitas seharihari. Selain itu dengan adanya teguran maupun himbauan langsung yang dilakukan secara terus menerus .

f. Tumbuhnya kebersamaan yang terjalin diantara setiap orang dipegayaman untuk membangun desanya. Kebersamaan ini sangat terasa ketika secara bersama-sama masyarakat membangun jalan raya secara gotong royong dengan penuh semangat dan kerelaan mereka untuk meluangkan waktu, fikiran dan tenaga .

g. Tingginya semangat masyarakat untuk saling mengasihi satu sama lain meskipun dengan latar belakang yang berbeda sebab mereka menganggap semua manusai pada dasarnya ialah saudara. Ajaran ini merupakan nilai yang terkandung di dalam budaya Nyama Beraya yang mendorong masyarakat untuk senantiasa melakukannya secara spontan tanpa adanya intruksi maupun tekanan dari pihak manapun. Selain itu bentuk kasih sayang mereka terhadap sesama atau yang mempunyai latar bealakang berbeda diwujudkan dengan berbagai bentuk kegiatan seperti Ngejot yang memiliki makna yang tinggi bagi masyarakat pegayaman .

h. Tingginya semangat masyarakat untuk menjaga tradisi dan mengembangan kesenian yang sudah diajarkan oleh leluhur. Tradisi dan kesenian warisan leluhur yang ada di pegayaman sampai saat ini terus dijaga dan di pertahankan sebab merupakan media mereka untuk senantiasa melestarikan budaya Nyama Beraya ini . Dengan spirit ini akan menumbuhkan rasa untuk saling memiliki dan kewajiban untuk merawat serta melestarikannya .

Dampak dari internalisasi nilai-nilai multikultural tersebut secara spontan mempengaruhi dan mendorong masyarakat pegayaman untuk senantiasa mempertahankan tradisi leluhur melalui pembiasaan dan pembudayaan yang digalakkan dalam perilaku kehidupan sehari-hari serta berkelanjutan. Adapun impact tersebut mendarah daging dalam diri masyarakat pegayaman dan sulit untuk ditinggalkan sebab terjadi bukan sekedar pada ranah penanaman nilai dan pengamalannya dalam kehidupan sehari-hari namun menyentuh ranah penghayatan yang menghasilkan buah berupa karakter toleransi .

\section{Temuan Lapangan}

Temuan dari penelitian ini adalah peran serta masyarakat muslim pegayaman dalam menginternalisasikan nilai-nilai multikultural dalam budaya Nyama Beraya dalam membentuk masyarakat yang berbudaya melalui tradisi ajaran leluhur dan dorongan dalam mengembangkan manusia yang berkarakter guna menjaga persatuan atas dasar talipersaudaraan dan saling mengasihi sesama manusia tanpa disekat oleh perbedaan satu sama lain. Namun menjadikannya sebagai kekuatan masyarakat dalam menyongsong kehidupan madani (berkemajuan) di tengah-tengah gerusan arus globlalisasi dan konflik horizontal yang marak akhir-akhir ini. Adapun penjelasan dari temuan penelitian tersebut secara terperinci dapat di jelaskan pada temuan yang terdapat di sub tema- sub tema pembahasan berikut:

\section{Eksistensi Budaya Nyama Beraya di Kampung Pegayaman}

Temuan penelitian pada sub tema ini ialah kentalnya akulturasi budaya yang diajarkan oleh leluhur mereka (warga pegayaman di masa lampau) kepada generasi penerus secara turun-temurun sampai saat ini dengan mempertankan konsep Nyama Beraya sebagai tradisi yang harus di pegang kuat dan harus di pertahankan. Nyama Beraya merupakan suatu konsep yang diajarkan oleh lelulur masyarakat pegayaman kepada generasi penerus yang mengandung nilai-nilai persaudaraan antar sesama manusia dengan saling mangasihi satu sama lain atas dasar bahwa kepercayaan setiap orang harus dihargai dan tidak boleh disamakan bahkan dipaksakan untuk sama 
dengan apa yang diyakini oleh seseorang. Mereka yang beragama hindu mendapat julukan Nyama Bali ( saudara hindu) dan mereka yang beragama islam mendapat julukan Nyama Selam ( saudara muslim).

Nyama Beraya yang berkembang di lingkungan masyarakat pegayaman sangat menghargai keberagaman dan kebebasan berekspresi namun tidak mentolerir suatu gerakan radikal dan paham idiologi atau agama yang keras ,fanatik dan berusaha merusak tradisi yang sudah berjalan selama berabad-abad lamanya. Nyama Beraya telah mendorong relasi islam dan hindu untuk berakulturasi namun tidak melanggar akidah dan syariat islam serta menghargai pokok ajaran agama masing-masing .

Wujud dari berkembangnya Nyama Beraya di kalangan masyarakat muslim pengayaman ialah tradisi-tradisi yang diajarkan oleh para leluhur yang tetap bertahan hingga saat ini diantaranya:

a. Tradisi Ngejot (memberikan makanan pada saat perayaan hari besar islam idul fitri, idul adha, maulid nabi dan berbagai acara lainnya kepada mereka Nyama Bali (saudara hindu) begitupun sebaliknya mereka yang beragama hindu juga demikian dengan tidak menyalahi aturan pada ajaran agama masing-masing)

b. Penggunaan Nama Khas Bali kepada putra-putri pegayaman dan keturunan masyarakat pegayaman di luar kampung seperti Wayan Fauzi, Ketut Angki Susongko dan lain-lain.

c. Tradisi Sukok Sada Maulid Basa (Tradisi masyarakat pegayaman yang dilaksanakan besar-besaran setiap bulan maulud sebagai hasil akulturasi islam dan hindu yang terdiri dari beberapa ritual yaitu penjajahan, pegapean dan penambahan serta hadirnya 2 sokok sada pada saat acara yaitu sukok pajegan dan sukok base)

d. Jero Linggo ( merupakan musyawarah lintas agama yang diikuti oleh seluruh perangkat desa, kecamatan, Perwakilian Pmerintah Bali melalui aliansi adat dan Forum Kerukunan Umat Beragama)

e. Ejaan Iqro' ( ejaan iqra' yang digunakan oleh masyarakat pegayaman ialah menggunakan bahasa bali seperti alif ngematian nun baris duwur "an" dan alif ngebukenun baris duwur "An-na”)

Adapun faham yang dianut oleh masyarakat muslim pegayaman ialah ahlusunnah wal jamaah dengan berorientasi kepada 4 prinsip yaitu tawazun ( berimbang), tasamuh ( toleransi), taad'ul (adil) dan tawassut (moderat) sehingga sangat relevan dengan ajaran leluhur yaitu Menyama Beraya.

Selain itu kuatnya eksistensi budaya Nyama Beraya tidak bisa dilepaskan oleh bahasa dan kesenian yang ikut mewarnainya sebab bahasa yang digunakan ialah bahasa bali yang merupakan bahasa nenek moyang mereka( Nyama Bali) sehingga mempengaruhi cara berfikir dan bertidak dalam kehidupan sehari-hari. Sedangkan dalam keseniaan masyarakat pegayaman masih kental dengan akulturasi relasi islam dan hindu sebagai akibat dari saduran nenek moyang mereka yang sangat kental dan melekat sehingga pada saat penampilan seni burdah tidak bisa dilepaskan dari budaya hindu seperti alat musik, pakaian yang digunakan dan kidung yang dimainkan.

2. Proses Internalisasi Nilai-Nilai Multikultural Melalui Budaya Nyama Beraya Pada Masyarakat Muslim Pegayaman

Temuan pada sub tema ini ialah Proses internalisasi nilai-nilai multikultural dilakukan dengan berbagai cara diantaranya perintah, nasehat, teguran, suri tauladan, teguran, pembiasaan dan diskusi diberbagai rutinitas kehidupan sehari-hari masyarakat muslim pengayaman baik dirumah, sekolah dan masyarakat. Hal tersebut sangat nampak sekali ketika menyelenggarakan acara adat dimana sebelum acara dimulai selalu budayawan adat dan ketua badan permusyawaratan desa menekankan kepada 
seluruh masyarakat pegayaman dan pendatang untuk senantiasa menjunjung nilai-nilai toleransi seperti apa yang diajarkan para leluhur dengan mempertahankan Nyama Beraya sebagai tradisi yang harus di lanjutkan dan di pegang teguh dalam diri setiap orang di lingkungan masyarakat pegayaman.

Selain itu penanaman nilai juga dilakukan saat siswa melaksanakan proses belajar di sekolah dan pengajian di rumah warga setiap pagi habis subuh dan habis magrib. Sedangkan pada kalangan remaja dan orang tua proses penanaman nilai-nilai multikultural melalui budaya Nyama Beraya dilakukan saat ada rapat FKUB sekecamatan sukasada yang melibatkan banyak pihak dan ketika pergelaran seni burdah serta ketika mereka saling berkumpul dan bertemu ketika dihadapkan dengan suatu masalah seperti perkelahian antar pelajar .

Dari semua media pendorong proses penanaman nilai-nilai multikultural tersebut terjadi interaksi antar individu yang sangat memungkinkan terjadinya pembiasaan , nasehat, teguran, suri tauladan, diskusi dan perintah yang tidak bisa dihindari . Hal yang sangat unik ialah proses penanaman nilai yang dilakukan secara bersamaan dan menyeluruh di semua rutinitas masyarakat pegayaman yang terjadi berulang-ulang dengan tidak hanya fokus pada interaksi satu arah namun berbagai arah serta dilaksanakan oleh semua masyarakat pegayaman sebagai bagian dari hidup mereka.

3. Strategi Internalisasi Nilai-Nilai Multikultural Melalui Budaya Nyama Beraya Pada Masyarakat Muslim Pegayaman

Temuan pada sub tema ini ialah strategi yang dilakukan oleh masyarakat muslim pegayaman untuk menanamkan nilai-nilai multikultural melalui budaya Nyama beraya meliputi 3 strategi yaitu indoktrinasi, kebebasan untuk menerima nilai dan penanaman nilai yang melalui 3 tahapan yaitu transformasi nilai, transaksi nilai dan transinternalisasi nilai. Ketiga strategi ini sangatlah dominan digunakan oleh masyarakat pegayaman untuk menginternalisasi/menanamkan nilai sebagaimana contoh dari setiap strategi diatas yang bisa peneliti jabarkan sebagai berikut:

a. Strategi indoktrinasi dilakukan dalam berbagai aktifitas dan kegiatan yang diselenggrakan oleh berbagai pihak melalui penyuluhan dan pemberian informasi kepada masyarakat semisal seminar dan diskusi terkait budaya Nyama Beraya dan batas toleransi umat lintas agama yang diselenggarakan di IAHN (Institut Agama Hindu Negeri ) Denpasar. Acara tersebut diikuti oleh forum komunikasi umat beragama (FKUB), aliansi adat nusantara, akademisi kampus dan masyarakat umum. Adapun indroktrinasi yang kami galakkan ialah mengajak masyarakat pegayaman dan Bali pada umumnya untuk memegang teguh ajaran leluhur kita yaitu Nyama beraya dengan menghormati ajaran dari agama dan kebuyaan masing-masing serta tidak mencampuradukkannya .

b. Strategi kebebasan dalam menerima nilai dilakukan dengan memberikan ruang dan kebebasan berekspresi kepada setiap individu untuk melakukan semua kegiatan / rutinitasnya dengan tidak melanggar ajaran leluhur kami yaitu Nyama Beraya ( semua adalah saudara dan harus saling mengasihi ). Sebagai contoh mereka boleh tidak ikut tradisi Ngejot, Sokok Sada Maulid Basa dan lain sebagainya namun jangan sampai membuat kerusuhan di kampung pengayaman ini seperti membawa isu sara, berkelahi antar pelajar, doktrin aliran keras keagamaan yang bertentangan dengan ajaran islam ahlusunnah wal jamaah.

c. Strategi internalisasi dilakukan dengan cara menanamkan nilai-nilai multikultural kepada siapapun yang tinggal dan hidup di kampung pegayaman ini melalui budaya Nyama Beraya di lintas rutinitas kegiatan warga baik itu disekolah, di rumah, di lingkungan masyarakat bahkan ketika acara adat dan pergelaran seni di 
selenggarakan. Adapun penanamannya dilakukan secara berulang-ulang dan bersamaan secara kontinu serta dapat di aplikasikan dalam kehidupan sehari-hari.

\section{Dampak Internalisasi Nilai-Nilai Multikultural Melalui Budaya Nyama Beraya Pada Masyarakat Muslim Pegayaman.}

Temuan pada sub tema ini ialah masyarakat secara langsung maupun tidak langsung sadar akan pentingnya ajaran leluhur mereka yaitu Menyama Beraya. Dimana dalam konsep ini jika dipahami sesungguhnya kehidupan yang penuh dengan keberagamaan ini merupakan ciptaan allah dan menjadi indah serta berkesan mana kala kita menggapnya sebagai bagian dari diri kita walaupun itu berbeda dengan mengganggap perbedaan adalah rahmatan lil alamin yang harus di jaga melalui kebersamaan dan persaudaraan yang diikat oleh tali kasih sayang.

Selain itu dampak yang sangat dominan dari internalisasi nilai-nilai multikultural melalui budaya Nyama Beraya di desa Pegayaman ini yang mayoritas muslim ialah tingginya semangat masyarakat pegayaman dalam mempertahankan dan mengembangkan budaya Nyama Beraya, semakin minimnya konflik antar remaja, SARA dan kepentingan yang mengatasnamakan pilihan politik, tingginya antusias masyarakat dalam merajut persatuan dan kesatuan bangsa, tingginya antusias masyarakat muslim pegayaman dalam menjaga dan mengembangkan kesenian yang diajarkan oleh para leluhurnya, tumbuhnya kebersamaan dalam membangun desa serta terbukanya masyarakat pegayaman terhadap pendatang yang masuk desa yang ingin menggali informasi terkait budaya Nyama Beraya.

5. Sinkronisasi Teori di Kajian Pustaka halaman 12- 16 Sub Bab dan Penemuan di Lapangan Terkait Internalisasi Nilai-Nilai Multikultural Melalui Budaya Nyama Beraya Pada Masyarakat Muslim Pegayaman Dapat Dijelaskan Pada Kedua Tabel Berikut:

Tabel 2. 1

Sinkronisasi Tahapan Penemuan dan Proses Internalisasi Pada Teori

\begin{tabular}{|l|l|l|}
\hline NO & Proses Internalisasi Pada Teori & Proses Internalisasi Pada Temuan di Lapangan \\
\hline 1 & $\begin{array}{l}\text { Transformasi Nilai(menginformasikan } \\
\text { suatu nilai tertentu) atau fase knowing }\end{array}$ & $\begin{array}{l}\text { Penanaman Nilai (perintah, nasehat, teguran, } \\
\text { suri tauladan, pembiasaan dan diskusi) }\end{array}$ \\
\hline 2 & $\begin{array}{l}\text { Transaksi Nilai ( interaksi timbal balik } \\
\text { untuk melakukan transaksi nilai) atau } \\
\text { fase doing }\end{array}$ & $\begin{array}{l}\text { Pengamalan Nilai ( mendarah daging dan } \\
\text { membudaya di tengah masyarakat serta menjadi } \\
\text { pembiasaan dalam kehidupan sehari-hari) }\end{array}$ \\
\hline 3 & $\begin{array}{l}\text { Transinternalisasi Nilai ( transaksi } \\
\text { interaktif terhadap suatu nilai disertai } \\
\text { dengan penerapan kepribadian figur } \\
\text { teladan secara nyata) atau fase Being }\end{array}$ & $\begin{array}{l}\text { Penghayatan Nilai (peresapan nilai yang } \\
\text { merasuk kedalam jiwa setiap orang pegayaman } \\
\text { guna pembentukan mental dan kepribadian) }\end{array}$ \\
\hline
\end{tabular}

Tabel 2. 2

Sinkronisasi Strategi Temuan dan Strategi Internalisasi Pada Teori

\begin{tabular}{|l|l|l|}
\hline NO & Strategi Internalisasi Pada Teori & Strategi Internalisasi Pada Temuan Penelitian \\
\hline 1 & $\begin{array}{l}\text { Strategi Tradisional (memberitahukan } \\
\text { secara langsung nilai baik dan buruk) }\end{array}$ & $\begin{array}{l}\text { Strategi Tradisional ( indoktrinasi budaya } \\
\text { leluhur yaitu Nyama Beraya })\end{array}$ \\
\hline
\end{tabular}

16 | Achmad Fauzi, - Internalisasi Nilai-Nilai Multikultural Melalui Budaya Nyama Braya Pada Masyarakat Muslim Pegayaman 


\begin{tabular}{|c|c|c|}
\hline 2 & $\begin{array}{l}\text { Strategi Bebas ( tidak memberitahukan } \\
\text { suatu nilai namun memberikan } \\
\text { kesempatan memilih secara bebas) }\end{array}$ & $\begin{array}{l}\text { Strategi Bebas (memberikan peluang dan } \\
\text { kesempatan kepada seseorang untuk bebas } \\
\text { berekspresi tanpa tekanan dan intruksi dari } \\
\text { siapapun namun mendorong untuk } \\
\text { menemukan sendiri makna dari suatu nilai }\end{array}$ \\
\hline 3 & $\begin{array}{l}\text { Strategi Reflektif (bolak balik } \\
\text { menggunakan pendekatan teoritik ke } \\
\text { emperik) }\end{array}$ & - \\
\hline 4 & $\begin{array}{l}\text { Strategi Transinternal (cara untuk } \\
\text { mendidik nilai dengan melakukan } \\
\text { transformasi nilai, dilanjutkan dengan } \\
\text { transaksi lain dan transinternalisasi) }\end{array}$ & $\begin{array}{l}\text { Strategi Transinternal ( penanaman nilai kepada } \\
\text { individu melalui Nyama Beraya di lintas } \\
\text { kegiatan rutinitas warga yang terjadi secara } \\
\text { berulang-lang dan continue serta dilaksanakan } \\
\text { dalam kehidupan sehari-hari }\end{array}$ \\
\hline
\end{tabular}

\section{Kerangka Teoritik dari Kesimpulan Penelitian yang Dituangkan dalam Bentuk Peta Konsep}

\section{Bagan 2.1} Internalisasi Nilai-Nilai Multikultural Melalui Budaya Nyama Beraya Pada
Masyarakat Muslim Pegayaman

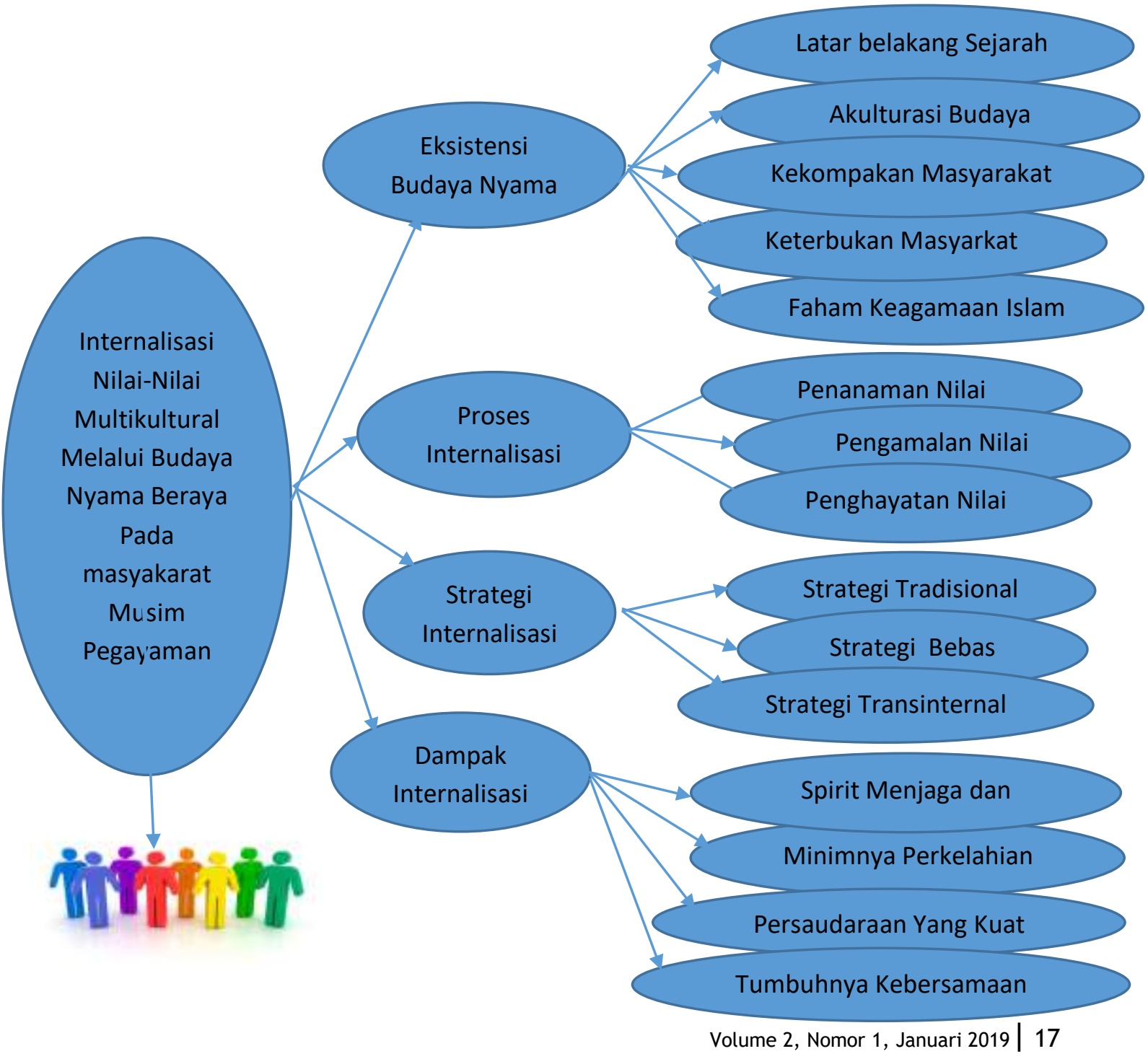




\section{Bagan 2.2}

\section{Eksistensi Budaya Nyama Beraya Pada Masyarakat Muslim Pegayaman}

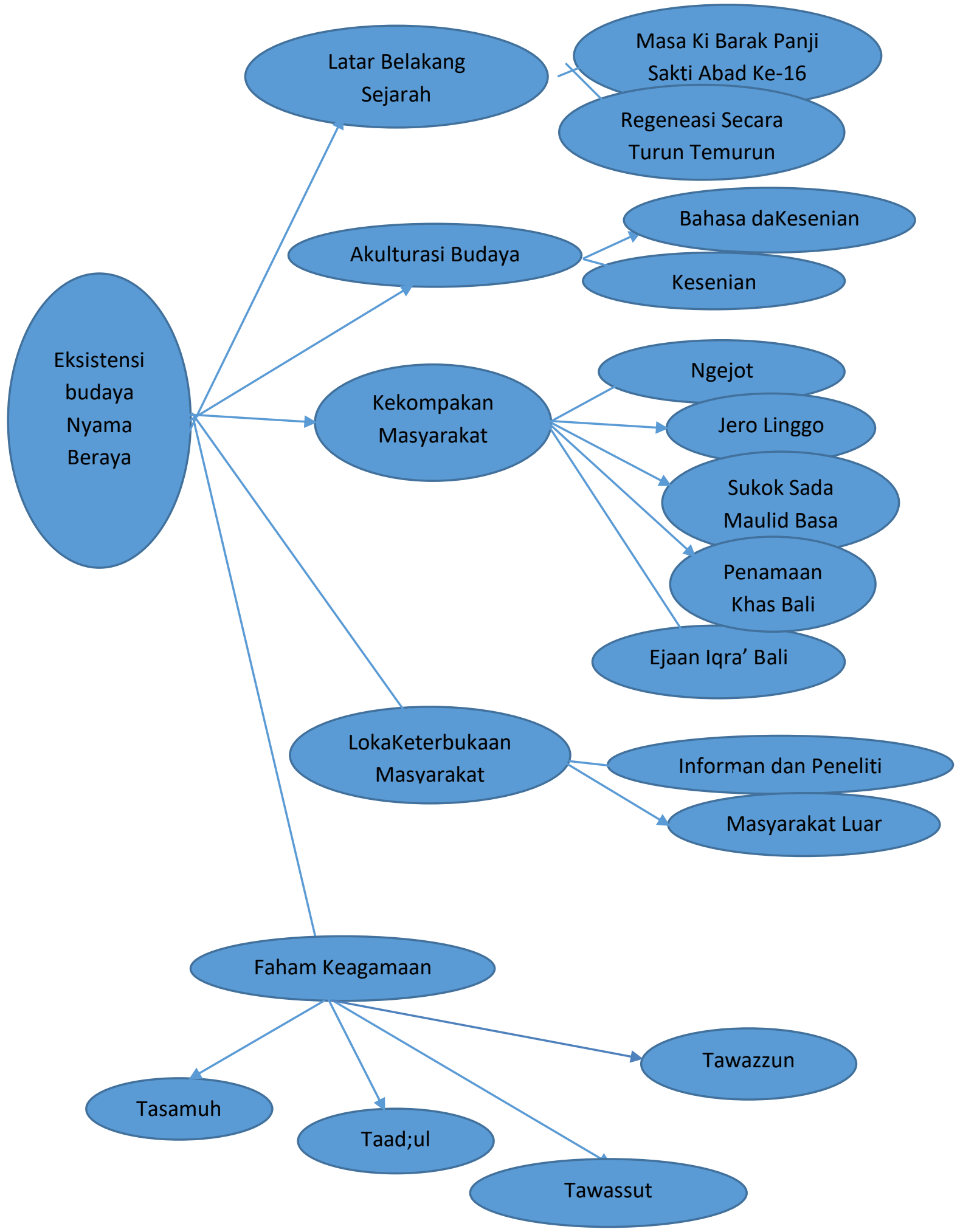

18 Achmad Fauzi, - Internalisasi Nilai-Nilai Multikultural Melalui Budaya Nyama Braya Pada Masyarakat Muslim Pegayaman 


\section{Kesimpulan}

Eksistensi budaya Nyama Beraya pada masyarakat muslim pegayaman disebabkan oleh beberapa faktor yang mempengaruhi diantaranya:

a. Latar belakang sejarah terbentuknya desa pegayaman sejak masa Ki Barak Panji Sakti abad ke-16 telah membentuk kepribadian masyarakat pegayaman sampai saat ini.

b. Akulturasi budaya hindu dan islam yang ikut mewarnai bahasa dan kesenian dalam kehidupan masyarakat pegayaman.

c. Kekompakan masyarakat pegayaman dalam melestarikan tradisi-tradisi yang diajarkan nenek moyangnya seperti ngejot, sukok sada maulid basa, jero linggo, penamaan khas bali pada nama depan mereka dan ejaan iqro' yang menggunakan bahasa bali.

d. Keterbukaan masyarakat pegayaman terhadap informan, peneliti dan masyarakat luar untuk mengekplorasi budaya Nyama Braya dan memperkenalkannya kepada khalayak umum.

e. Faham keagamaan islam yang dianut sebagian besar di kampung muslim pegayaman ialah ahlusunnah waljamaah yang memiliki 4 prinsip yaitu tawazzun ( berimbang), tasamuh (toleransi), taad'ul (adil) dan tawassut (moderat).

Sedangkan proses internalisasi nilai-nilai multikultural melalui budaya Nyama Beraya pada masyarakat muslim pegayaman melalui 3 tahapan yaitu:

a. Penanaman

Penanaman nilai dilakukan dengan menanamkan nilai kepada masyarakat pegayaman yang dilakukan dengan beberapa metode diantaranya perintah , nasehat, tauladan, teguran, pembiasaan dan diskusi.

b. Pengamalan

Pengamalan nilai merupakan kelanjutan dari penanaman nilai dimana pada tahap ini terjadi pembiasaan yang mengarah kepada terbentunya budaya Nyama Beraya di desa pegayaman. Kebiasaan tersebut dilakukan secara terus menerus baik itu secara langsung.

c. Penghayatan

Penghayatan nilai merupakan peresapan terhadap nilai-nilai yang sudah ditanamkan dan diamalkan dalam kehidupan sehari-hari.

Adapun strategi internalisasi nilai-nilai multikultural melalui budaya Nyama Beraya pada masyarakat muslim pegayaman terdiri dari :

a. Strategi Tradisional

Strategi ini ditempuh dengan memberikan informasi secara langsung terkait dengan nilai-nilai yang terkandung di dalam budaya Nyama Beraya kepada seseorang di dalam lingkungan masyarakat pegayaman melalui nasehat, teguran , perintah dan indoktrinasi.

b. Strategi Bebas

Strategi ini memberikan peluang dan kesempatan kepada seseorang di tengahtengah masyarakat pegayaman untuk bebas berekspresi tanpa tekanan dan intruksi dari siapapun namun justru sebaliknya individu tersebut menemukan sendiri 
secara langsung maupun tidak langsung nilai-nilai yang terkandung di dalam budaya Nyama Beraya.

c. Strategi Transinternal

Strategi ini ditempuh dengan mentransfer nilai-nilai yang terkandung dalam budaya Nyama Beraya melalui penanaman nilai kepada seseorang dengan tujuan orang tersebut melaksanakannya dalam kehidupan sehari hari dan menjadikannya sebagai rutinitas yang tidak terlepas dari nilai-nilai budaya. Jika hal ini terjadi secara terus menerus akan menyebabkan masuknya nilai-nilai tersebut kedalam diri individu dan individu tersebut dapat menghayatinya sehingga dalam melakukan segala aktivitas tidak ada beban dan keragu-raguan namun penuh dengan percaya diri.

Dampak internalisasi nilai-nilai multikultural melalui budaya Nyama Beraya pada masyarakat muslim pegayaman meliputi:

a. Tidak ada konflik yang mengatasnamakan agama mapun golongan di pegayaman.

b. Tingginya semangat masyarakat pegayaman untuk merajut persatuan dan mencegah munculnya radikalisme di lingkungan sekitar.

c. Tumbuhnya kebersamaan yang terjalin diantara setiap orang di pegayaman untuk membangun desanya.

d. Tingginya semangat masyarakat untuk saling mengasihi satu sama lain meskipun dengan latar belakang yang berbeda sebab mereka menganggap semua manusai pada dasarnya ialah saudara.

e. Tingginya semangat masyarakat untuk menjaga tradisi dan mengembangan kesenian yang sudah diajarkan oleh leluhur.

f. Ramahnya sambutan masyarakat terhadap siapapun termasuk tamu yang datang ke pegayaman.

g. Kepatuhan masyarakat pegayaman terhadap ajaran leluhurnya.

\section{Daftar Pustaka}

Alwisol, 2007, Psikologi Kepribadian, Malang: UNMU.

Arismantoro, 2008, Character Building: Bagaimana Mendidik Anak Berkarakter, Yogyakarta: Tiara Wacana.

Assegaf, Abd. Rahman, 2005, Politik Pendidikan Nasional, Yogyakarta: Kurnia Kalam.

Bakran al-Dzaky, M. Hamdani, 2002, Konseling dan Psikoterapi Islam Penerapan Metode Sufistik, Yogyakarta, Fajar Pustaka Baru.

Basyir, Kunawi, 2016, Membangun Kerukunan Antarumat Beragama berbasis Budaya Lokal Menyama Braya di Denpasar Bali dalam Jurnal Religio, Vol. 6, No.2.

Halili \& Naipospos, Bonar Tigor, 2015, Laporan Kondisi Kebebasan Beragama/Berkeyakinan Di Indonesia Tabun 2015, Politik. Harapan Minim Pembuktian, Bendungan Hilir: Pustaka Masyarakat Setara.

Muhaimin, 1996, Srategi Belajar Mengajar, Surabaya: Citra Media.

Mustafa Zahri, Mustafa, 1995, Kunci Memahmi Ilmu Tasawnf, Surabaya: Bina Ilmu.

Muhaimin, 2004, Paradigma Pendidikan Islam: Upaya Mengaktifkan Pendidikan Agama Islam di Sekolah, Bandung: PT Remaja Rosdakarya.

Naim, Ngainun \& Sauqi, Achmad, 2011, Pendidikan Multikultural Konsep dan Aplikasi, Yogyakarta: ArRuzz Media.

Nasikun, 1995, Sistem Sosial Indonesia, Jakarta: PT Raja Grafindo Persada.

Pageh, I. M, Sugiartha,Wayan \& Artha, Ketut Sedana, 2013, Analisis Faktor Integratif Nyama Bali-Nyama Selam, Untuk Menyusun Buku Panduan Kerukunan

20 | Achmad Fauzi, - Internalisasi Nilai-Nilai Multikultural Melalui Budaya Nyama Braya Pada Masyarakat Muslim Pegayaman 
Masyarakat di Era Otonomi daerah dalam Jurnal Ilmu Sosial dan Humaniora, Vol. 2, No. 2.

Purna, I Made, 2016, Kearifan lokal Masyarakat Desa Mbawa Dalam Mewujudkan Toleransi Beragama dalam Jurnal Pendidikan dan Kebudayaan, Vol. 1, No. 2.

Ramayulis, 2002, Pengantar Psikologi Agama, Jakarta: Kalam Mulia.

Rumagit, Stev Koresy, 2013, Kekerasan dan Diskriminasi Antar Umat Beragama di Indonesia dalam Jurnal Lex Administratum, Vol. I, No.2.

Suryawan, Nyoman, 2017, Kearifan lokal sebagai modal sosial dalam integrasi antara etnik Bali dan etnik Bugis di desa Petang, Badung, Bali dalam Jurnal Kajian Bali , Vol. 7, No. 1.

Suwindia , I.G, Machasin \& Parimartha, I.G, 2012, Relasi Islam dan Hindu Perspektif Masyarakat Bali dalam Jurnal Al-Ulum, Vol. 12, No. 1.

Suryadinata, Leo, Arifin, Evi Nurvida, 2003, Penduduk Indonesia, Jakarta: LP3ES.

Syamsul Arifin, 2009, Studi Agama (Perspektif Sosiologis dan Isu-isu Kontemporer), Malang: UMM Press.

Tim Penyusun, 2014, Laporan Tabunan Kebebasan Beragama / Berkeyakinan Dan Intoleransi 2014 The Wabid Institute, Jakarta: The Wahid Institute.

Tobroni, 2007, Pendidikan kewarganegaraan Demokrasi, HAM, Civil Society dan Multikultural, Yogyakarta: PusaPom.

Tafsir, Ahmad, 2006, Filsafat Pendidikan Islam, Integrasi Jasmani, Rohani, dan Kalbu Memanusiakan Manusia (Bandung: Remaja Rosdakarya, 2006), 229.

Yamin, Moh \& Aulia, Vivi, 2011, Meretas Pendidikan Toleransi : Pluralisme dan Multikulturalisme keniscayaan Peradaban, Malang: Madani Media.

Yasin, A. Fatah , 2008, Dimensi-Dimensi Pendidikan Islam, Malang: UIN MALANG PRESS.

Winkel, W.S. \& Hastuti, Sri, 2004, Bimbingan dan Konseling di Institusi Pendidikan, Jogjakarta:

Media Abadi. 